Prepared in cooperation with Colorado Department of Public Health and Environment

\title{
Analysis of Dissolved Selenium Loading from Surface Water and Groundwater to Sweitzer Lake, Colorado, 2006-07
}

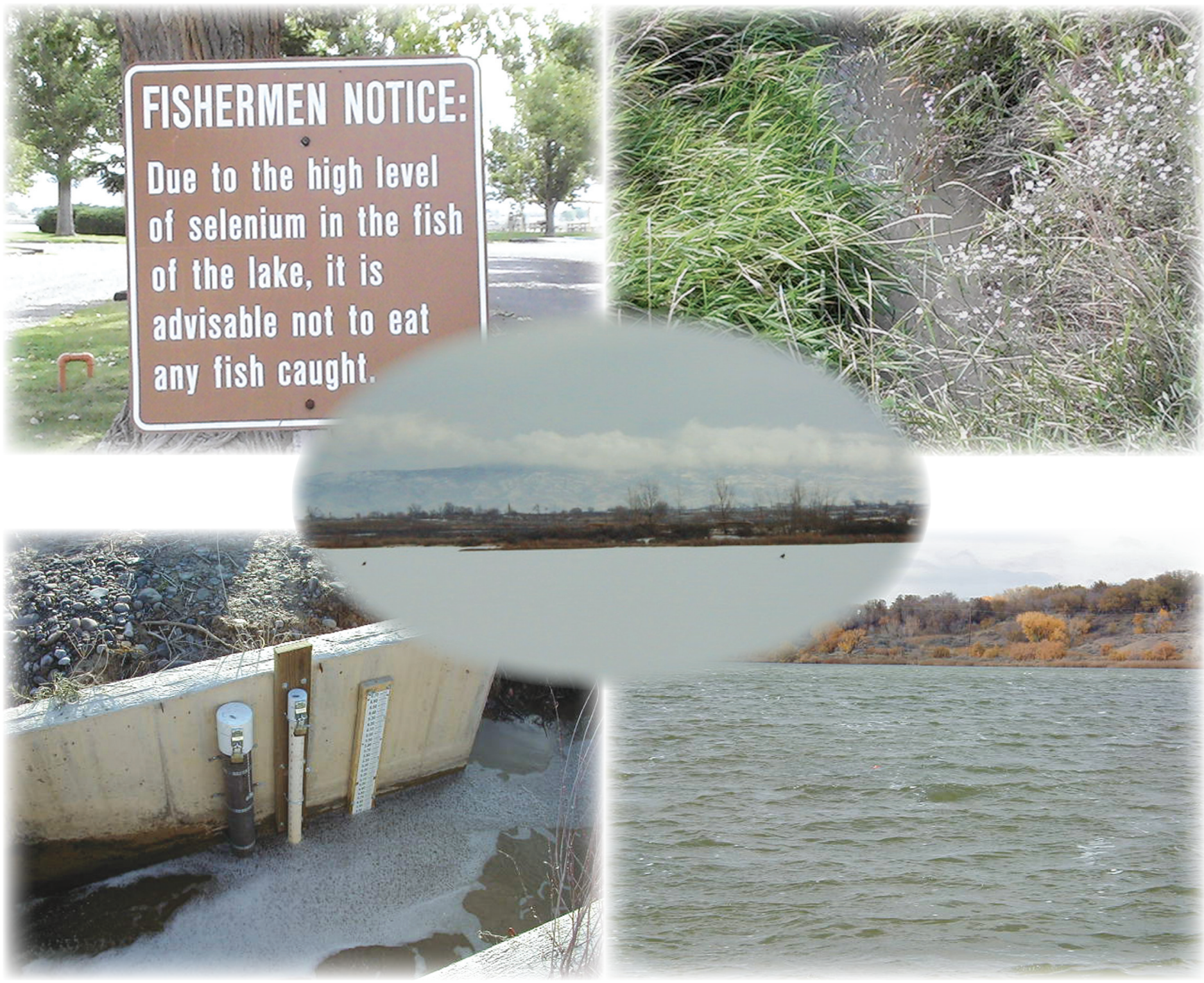

Scientific Investigations Report 2009-5048 


\section{Cover:}

Photo 1 (upper left): Sign posted at Sweitzer Lake State Park, western Colorado

Photo 2 (upper right): Garnet Canal Diversion at Sweitzer Lake State Park, western Colorado

Photo 3 (lower left): Diversion drain gage at Sweitzer Lake State Park, western Colorado

Photo 4 (lower right): Sweitzer Lake facing northwest, Sweitzer Lake State Park, western Colorado

Photo 5 (center): Sweitzer Lake facing north, Sweitzer Lake State Park, western Colorado

Photographs by Paul Diaz, Jr., U.S. Geological Survey 


\section{Analysis of Dissolved Selenium Loading from Surface Water and Groundwater to Sweitzer Lake, Colorado, 2006-07}

By Judith C. Thomas

Prepared in cooperation with Colorado Department of

Public Health and Environment

Scientific Investigations Report 2009-5048 


\title{
U.S. Department of the Interior \\ KEN SALAZAR, Secretary
}

\author{
U.S. Geological Survey \\ Suzette M. Kimball, Acting Director
}

U.S. Geological Survey, Reston, Virginia: 2009

For more information on the USGS - the Federal source for science about the Earth, its natural and living resources, natural hazards, and the environment, visit http://www.usgs.gov or call 1-888-ASK-USGS

For an overview of USGS information products, including maps, imagery, and publications, visit http://www.usgs.gov/pubprod

To order this and other USGS information products, visit http://store.usgs.gov

Any use of trade, product, or firm names is for descriptive purposes only and does not imply endorsement by the U.S. Government.

Although this report is in the public domain, permission must be secured from the individual copyright owners to reproduce any copyrighted materials contained within this report.

Suggested citation:

Thomas, J.C., 2009, Analysis of dissolved selenium loading from surface water and groundwater to Sweitzer Lake, Colorado, 2006-07: U.S. Geological Survey Scientific Investigations Report 2009-5048, 19 p.

\section{Library of Congress Cataloging-in-Publication Data}

Thomas, Judith Coffman, 1972-

Analysis of dissolved selenium loading from surface water and groundwater to Sweitzer Lake, Colorado, 2006-07 / by Judith C. Thomas.

p. cm. -- (Scientific investigations report ; 2009-5048)

"Prepared in cooperation with Colorado Department of Public Health and Environment."

Includes bibliographical references.

ISBN 978-1-4113-2540-1

1. Selenium--Environmental aspects--Colorado. 2. Water--Pollution--Colorado. I. Colorado. Dept. of Public Health and Environment. II. Geological Survey (U.S.) III. Title. IV. Series: Scientific investigations report ; 2009-5048.

TD224.C7T56 2009

628.1'680978818--dc22 


\section{Contents}

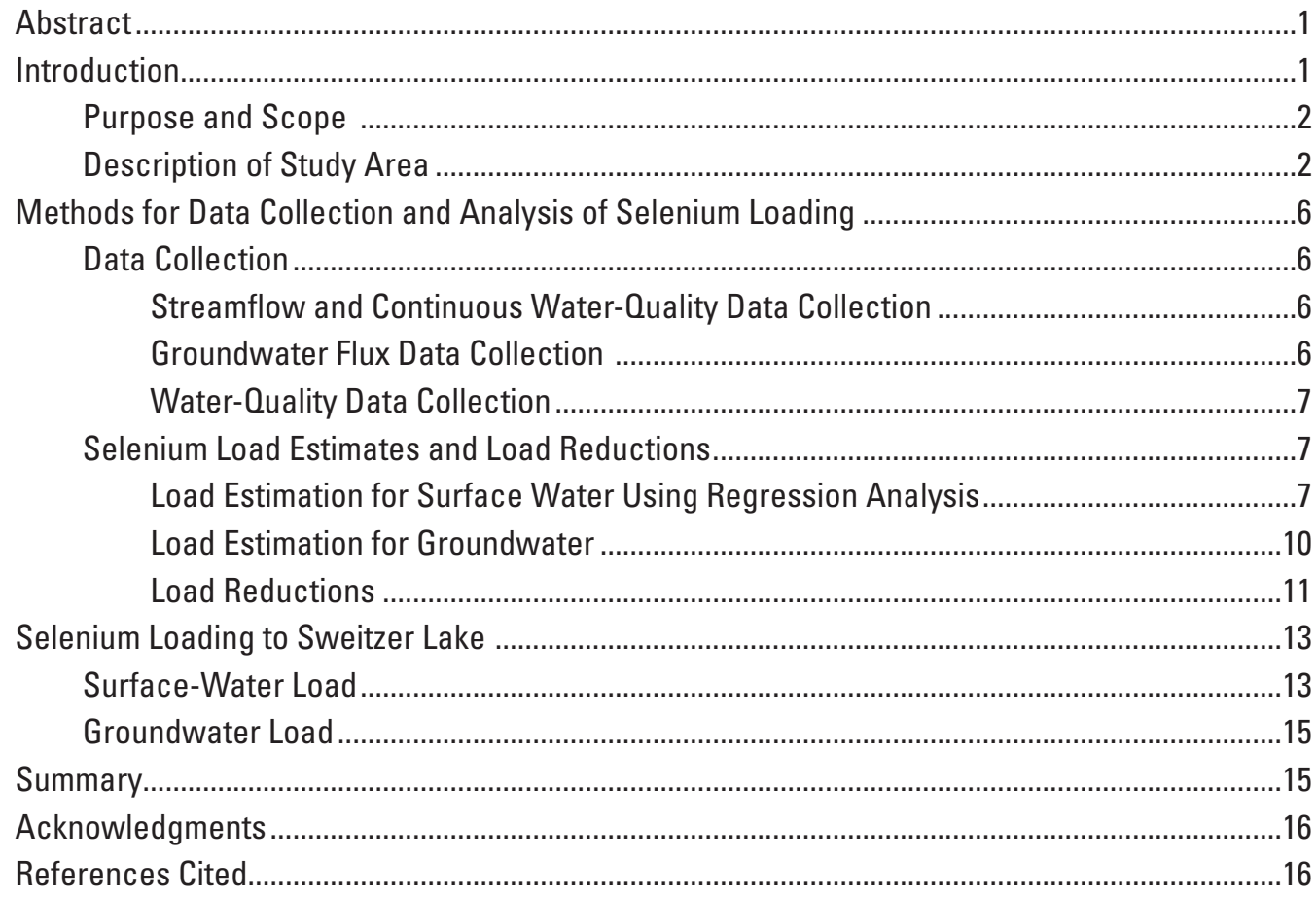

\section{Figures}

1. Location of Sweitzer Lake, near Delta, western Colorado, showing

$(A)$ the study area and $(B)$ area adjacent to the study area ...........................................

2. Selected land-use types adjacent to Sweitzer Lake, western Colorado ...........................

3. Selected geologic units outcropping adjacent to Sweitzer Lake, western Colorado.......5

4. Scatter plot of instantaneous specific conductance in relation to selenium concentration data collected for this study at SW-1 and SW-2, October 2006 to October 2007

5. Results of groundwater flux analysis for Sweitzer Lake, western Colorado, October 2006 to October 2007.

6. Time series plots of daily mean streamflow, selenium concentration, selenium load, and selenium samples for $(A)$ Garnet Canal Diversion (site SW-1) and (B) Diversion Drain (site SW-2), near Sweitzer Lake, western Colorado 


\section{Tables}

1. Summary of regression model diagnostics for two surface-water sites that are sources of inflow to Sweitzer Lake, western Colorado,

October 2006 to October 2007

2. Summary of groundwater flux data collected for each site indicating overall direction of groundwater flux at Sweitzer Lake, western Colorado, October 2006 to October 2007

3. Estimated selenium concentration and loads in surface-water inflow to Sweitzer Lake, western Colorado, October 2006 to October 2007. .8

4. Summary of groundwater selenium concentration and load scenarios to Sweitzer Lake, western Colorado, October 2006 to October 2007.

\section{Conversion Factors and Datums}

\begin{tabular}{lll}
\hline Multiply & \multicolumn{1}{c}{ By } & \multicolumn{1}{c}{ To obtain } \\
\hline & \multicolumn{1}{c}{ Length } \\
\hline inch (in.) & 2.54 & centimeter $(\mathrm{cm})$ \\
foot $(\mathrm{ft})$ & 0.3048 & meter $(\mathrm{m})$ \\
mile $(\mathrm{mi})$ & 1.609 & kilometer $(\mathrm{km})$ \\
\hline \multicolumn{3}{c}{ Flow rate } \\
\hline cubic foot per second $\left(\mathrm{ft}^{3} / \mathrm{s}\right)$ & 0.02832 & cubic meter per second $\left(\mathrm{m}^{3} / \mathrm{s}\right)$ \\
\hline \multicolumn{2}{c}{ Mass } \\
\hline pound, avoirdupois $(\mathrm{lb})$ & 0.4536 & kilogram $(\mathrm{kg})$ \\
pound per day $(\mathrm{lb} / \mathrm{d})$ & 0.4536 & kilogram per day $(\mathrm{kg} / \mathrm{d})$ \\
pound per year $(\mathrm{lb} / \mathrm{y})$ & 0.4536 & kilogram per year $(\mathrm{kg} / \mathrm{y})$ \\
\hline
\end{tabular}

Temperature in degrees Fahrenheit $\left({ }^{\circ} \mathrm{F}\right)$ may be converted to degrees Celsius $\left({ }^{\circ} \mathrm{C}\right)$ as follows:

$$
{ }^{\circ} \mathrm{C}=\left({ }^{\circ} \mathrm{F}-32\right) / 1.8
$$

Vertical coordinate information is referenced to the North American Vertical Datum of 1988 (NAVD 88).

Horizontal coordinate information is referenced to the North American Datum of 1983 (NAD 83). Specific conductance is given in microsiemens per centimeter at 25 degrees Celsius $(\mu \mathrm{S} / \mathrm{cm}$ at $\left.25^{\circ} \mathrm{C}\right)$.

Chemical concentrations are given in micrograms per liter $(\mu \mathrm{g} / \mathrm{L})$. 


\title{
Analysis of Dissolved Selenium Loading from Surface Water and Groundwater to Sweitzer Lake, Colorado, 2006-07
}

\author{
By Judith C. Thomas
}

\section{Abstract}

Elevated selenium concentrations in streams are a water-quality concern in western Colorado. Sweitzer Lake was placed on the State 303(d) list as impaired with respect to dissolved selenium. In Colorado, the Water Quality Control Division (Division) of the Colorado Department of Public Health and Environment is required to develop total maximum daily loads of selenium for the 303(d) list segments. The U.S. Geological Survey, in cooperation with Colorado Department of Public Health and Environment, summarized selenium loading from surface water and groundwater to Sweitzer Lake to support the total maximum daily loads development process. Surface-water and groundwater data were collected to quantify selenium concentrations and loads to Sweitzer Lake from October 2006 to October 2007. These data were used to determine the amount of the selenium load (pounds annually) that would need to be reduced for the contributing sources (surface water and groundwater) to meet the State chronic aquatic-life standard of 4.6 micrograms per liter for dissolved selenium, herein referred to as "a load reduction." Selenium concentration data were also compared to the State acute aquatic-life standard of 18.4 micrograms per liter for dissolved selenium. Both surface-water and groundwaterquality samples collected during this study were found to exceed the chronic standard. Surface-water quantity and quality data were collected at Garnet Canal Diversion and Diversion Drain. Groundwater flux data were collected at 10 seepage-meter sites in Sweitzer Lake, and groundwaterquality data were collected at a groundwater seep (seep-1) and inferred from a January 2007 sample collected at Garnet Canal Diversion. Selenium concentrations and loads were greater at Garnet Canal Diversion than those observed at Diversion Drain. Approximately one-third of Garnet Canal Diversion's streamflow originates from Loutzenhizer Arroyo. Selenium concentrations observed during previous studies at Loutzenhizer Arroyo indicate high selenium concentrations and high selenium loads. All selenium concentrations in samples from Garnet Canal Diversion were greater than the chronic standard and were less than the acute standard $(18.4 \mu \mathrm{g} / \mathrm{L})$ during the irrigation season. Seventy-three percent (or 35.9 pounds) of the annual selenium load at Garnet Canal Diversion would need to be reduced in order to meet the chronic standard. All daily mean selenium concentrations and selenium-concentration samples were greater than the chronic standard at Diversion Drain, but were less than the acute standard during the irrigation season. Forty percent (or 7.32 pounds) of the mean annual selenium load at Diversion Drain would need to be reduced in order to meet the chronic standard. Estimated groundwater selenium loads and reductions of selenium loads to Sweitzer Lake were estimated using ranges of lake-bottom areas with positive groundwater flux and groundwater selenium concentrations. Estimated annual groundwater selenium load reductions ranged from 0.900 pound of the 1.17 pounds of annual load to 86.3 pounds of the 88.3 pounds of annual load for the selenium concentration scenarios over the range of lake-bottom areas. Groundwater selenium load and load reductions determined from this study identify the probable minimum and maximum values for these parameters. Further data collection and analysis could refine the range of groundwater selenium loads and load reductions.

\section{Introduction}

Selenium is a trace element that occurs naturally in sedimentary rocks of western Colorado (Lakin and Byers, 1941, as cited in Seiler, 1997). Various human activities such as mining and agriculture can act to mobilize selenium. Selenium readily dissolves in oxygenated water and moves through the aquatic environment where it can bioaccumulate in organisms and potentially reach toxic levels (Lemly, 2002). Because of its elevated selenium concentrations, Sweitzer Lake was placed on the State 303(d) list as impaired for selenium (Colorado Department of Public Health and Environment, 2007a; 2007b). In Colorado, the Water Quality Control Division (Division) of the Colorado Department of Public Health and Environment (CDPHE) is required to develop total maximum daily loads for the 303(d) list segments (Colorado Department of Public Health and Environment, 2007a). Owing to the complexities associated with characterizing selenium fate and transport, the U.S. 
Geological Survey (USGS), in cooperation with CDPHE, collected and analyzed data to quantify selenium load and support the total maximum daily loads development process.

\section{Purpose and Scope}

This report provides an analysis of dissolved selenium load from contributing sources (surface water and groundwater) to Sweitzer Lake from October 2006 to October 2007, a brief description of the study area, data collection, and data-analysis methods. Selenium load to Sweitzer Lake from two surface-water sites during October 2006 to October 2007 and annual selenium load contributed to the lake from groundwater are estimated. Results include the assessment of selenium concentrations, 85 th percentile selenium concentrations, selenium loads, and quantification of the amount of selenium load (pounds annually) to Sweitzer Lake that would need to be reduced to bring the contributing sources (surface water and groundwater) into compliance with the State chronic aquatic-life standard for dissolved selenium. The portion of selenium load that would need to be reduced (herein referred to as a "load reduction") was determined when the 85th percentile selenium concentration exceeded the State chronic aquatic-life standard for dissolved selenium $(4.6 \mu \mathrm{g} / \mathrm{L}$ [micrograms per liter]), referred to as the "chronic standard" (Colorado Department of Public Health and Environment, 2007c). Surface-water and groundwater selenium loads and load reductions were both calculated in order to provide a comparison between the two contributing sources. Selenium concentrations from contributing sources were also compared to the State acute aquatic-life standard for dissolved selenium, which is $18.4 \mu \mathrm{g} / \mathrm{L}$, referred to as the "acute standard" (Colorado Department of Public Health and Environment, 2007c). Throughout the report, the use of the term "selenium" refers to dissolved selenium in micrograms per liter.

\section{Description of Study Area}

Sweitzer Lake is approximately 3 miles southeast of the town of Delta in Delta County, in west-central Colorado (fig. 1). Sweitzer Lake (also referred to in some literature as "Garnet Mesa Reservoir") was built in 1954 on land donated to the State of Colorado for use as a State Park recreation area. Sweitzer Lake has a surface area of 135 acres, a storage capacity of 1,330 acre-feet, and a maximum depth of 28 feet (Butler and others, 1991). The Colorado Division of Parks and Outdoor Recreation operates the park, and primary uses include boating, picnicking, limited waterfowl hunting, and fishing (Colorado State Parks, 2008). Elevated selenium concentrations have long been known to be a problem at Sweitzer Lake. The Colorado Division of Wildlife measured more than 100 milligrams per kilogram $(\mathrm{mg} / \mathrm{kg})$ selenium in muscle tissue of fish in 1974 and 1977. Based on this information, the Division of Wildlife decided to stop stocking fish to Sweitzer Lake in 1974 (Frankenberger and Engberg, 1998). Since 1977, a warning sign has been posted at the lake advising people not to eat fish caught from the lake (Butler and others, 1991). Concentrations of selenium in water samples collected from Sweitzer Lake during August, September, and October 1978, reportedly ranged from less than 5 to $45 \mu \mathrm{g} / \mathrm{L}$ (Butler and others, 1991).

The primary land-use surrounding Sweitzer Lake is agriculture (fig. 2) (Vogelmann and others, 2001). Although much of the area directly adjacent to Sweitzer Lake is not used for agriculture, the two surface-water inflows into Sweitzer Lake originate from and flow adjacent to agricultural lands. The two surface-water inflows receive streamflow from other irrigation canals and/or rivers. Garnet Canal Diversion off the Garnet Canal is located on the east end of the lake (fig. 1). Garnet Canal and consequently Garnet Canal Diversion receive streamflow from the Uncompahgre River and Loutzenhizer Arroyo (Steve Fletcher, Olathe Delta Watermaster, Montrose, Colorado, oral commun., 2008). The Uncompahgre River and Loutzenhizer Arroyo enter Garnet Canal approximately three and a one-half miles south of Garnet Canal Diversion (site SW-1 (fig.1)). Diversion Drain off the GF lateral is located on the south side of the lake (fig. 1). GF Lateral receives streamflow from East Canal, which is approximately 4 miles east of Diversion Drain at site SW-2 (fig. 1). East Canal receives its streamflow from the Uncompahgre River near Olathe, Colorado (Steve Fletcher, Olathe Delta Watermaster, Montrose, Colorado, oral commun., 2009). In addition to agricultural land use, residential and urban land-use development is increasing in the vicinity of Sweitzer Lake as population growth occurs (Gunnison Basin Selenium Task Force, 2007). Residential and urban land uses have the potential to introduce new paths of selenium loading to surface water and groundwater (Gunnison Basin Selenium Task Force, 2007). The 2006 population estimate for Delta was 8,366 compared to the 2000 population of 6,400 (U.S. Census Bureau, 2008).

Mancos Shale is the dominant bedrock material outcropping in the study area (fig. 3; Day and others, 1999) and is likely the source of selenium (Butler and others, 1996). Sweitzer Lake was constructed in an arroyo on the southwest side of Garnet Mesa (fig. 3). Surface deposits around and underlying Sweitzer Lake primarily are derived from the Mancos Shale (Butler and others, 1991, 1996). The Upper Cretaceous Mancos Shale is a massive, fossiliferous marine shale with interbedded sandstone, siltstone, and devitrified volcanic ash layers. The Mancos is the lateral equivalent to the Niobrara Formation, Cody Shale, and Pierre Shale in Colorado, Montana, Nebraska, South Dakota, and Wyoming (Wright and Butler, 1993).

Climate in the study area is predominantly semiarid, but some variation in climate occurs at higher elevations (in general, more precipitation and cooler temperatures occur at higher elevations). Average annual precipitation at Delta is 7.92 inches, including an average annual snowfall of 14.9 inches; average annual temperatures range from 33.8 to $67.1^{\circ} \mathrm{F}$ (Western Regional Climate Center, 2008). 

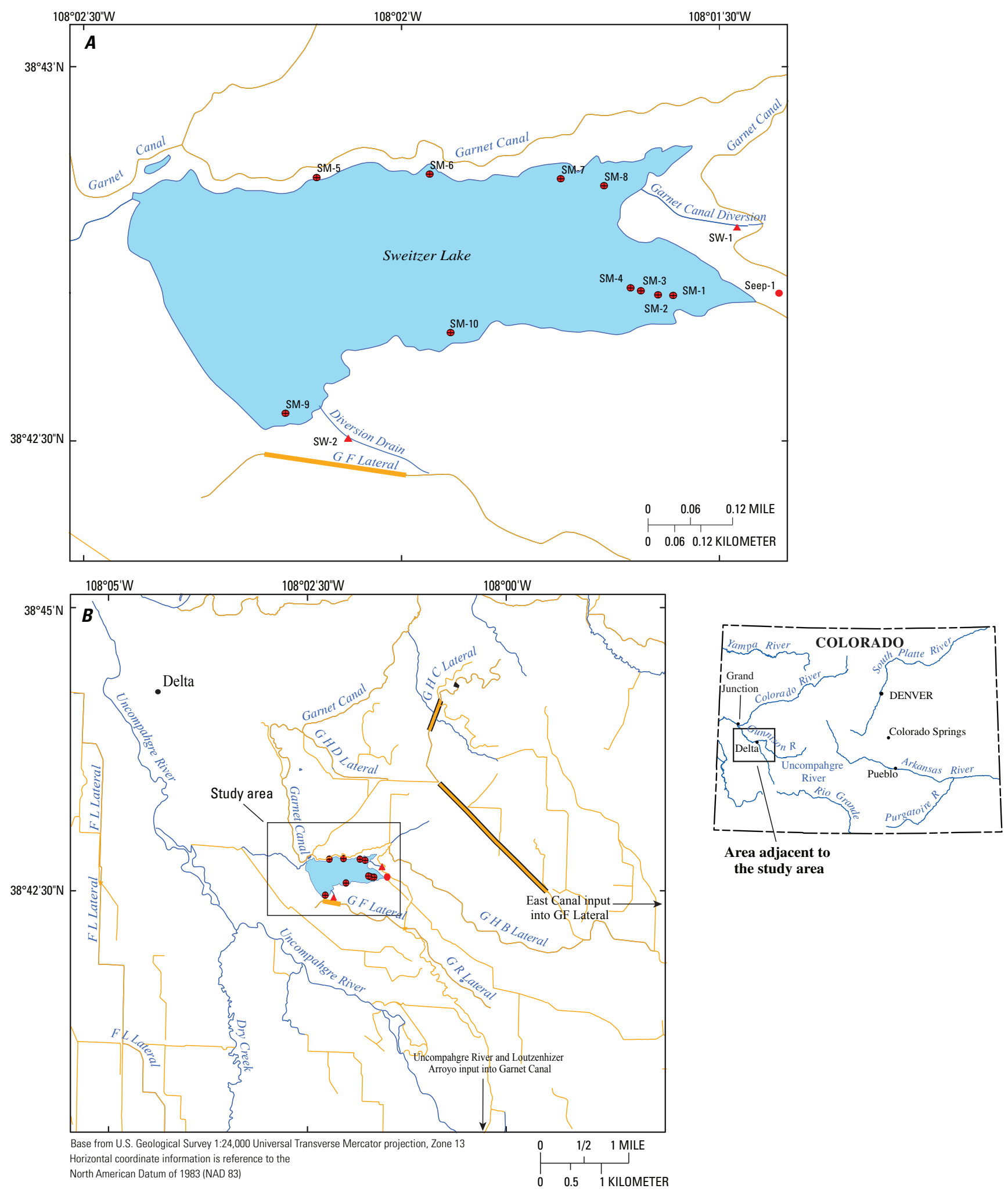

Area adjacent to

the study area

\section{EXPLANATION}

$\begin{array}{lll}\longleftarrow \text { Stream/River } & \Delta & \text { Surface-water sites } \\ \text { Canal/Ditch } & \bullet & \text { Seepage meter sites } \\ \text { Piped Canal/Ditch } & \bullet & \text { Groundwater site }\end{array}$

Figure 1. (on facing page) Location of Sweitzer Lake, near Delta, western Colorado, showing $(A)$ the study area and $(B)$ area adjacent to the study area. 


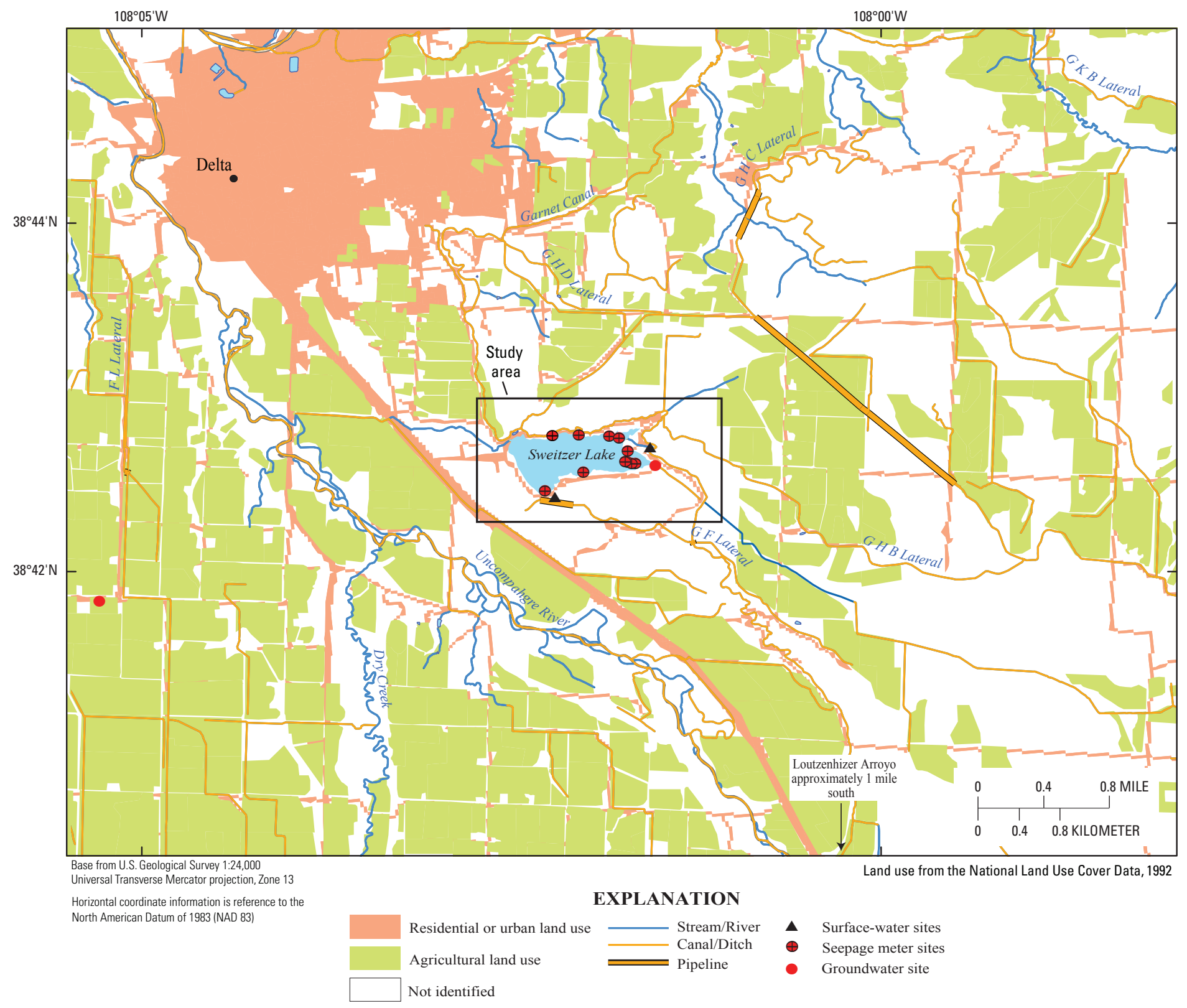

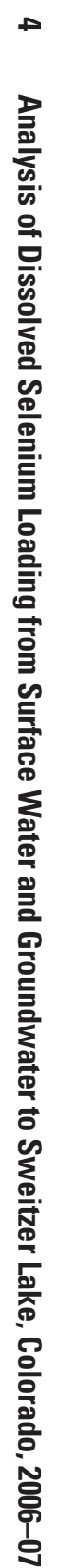

Figure 2. Selected land-use types adjacent to Sweitzer Lake, western Colorado. 


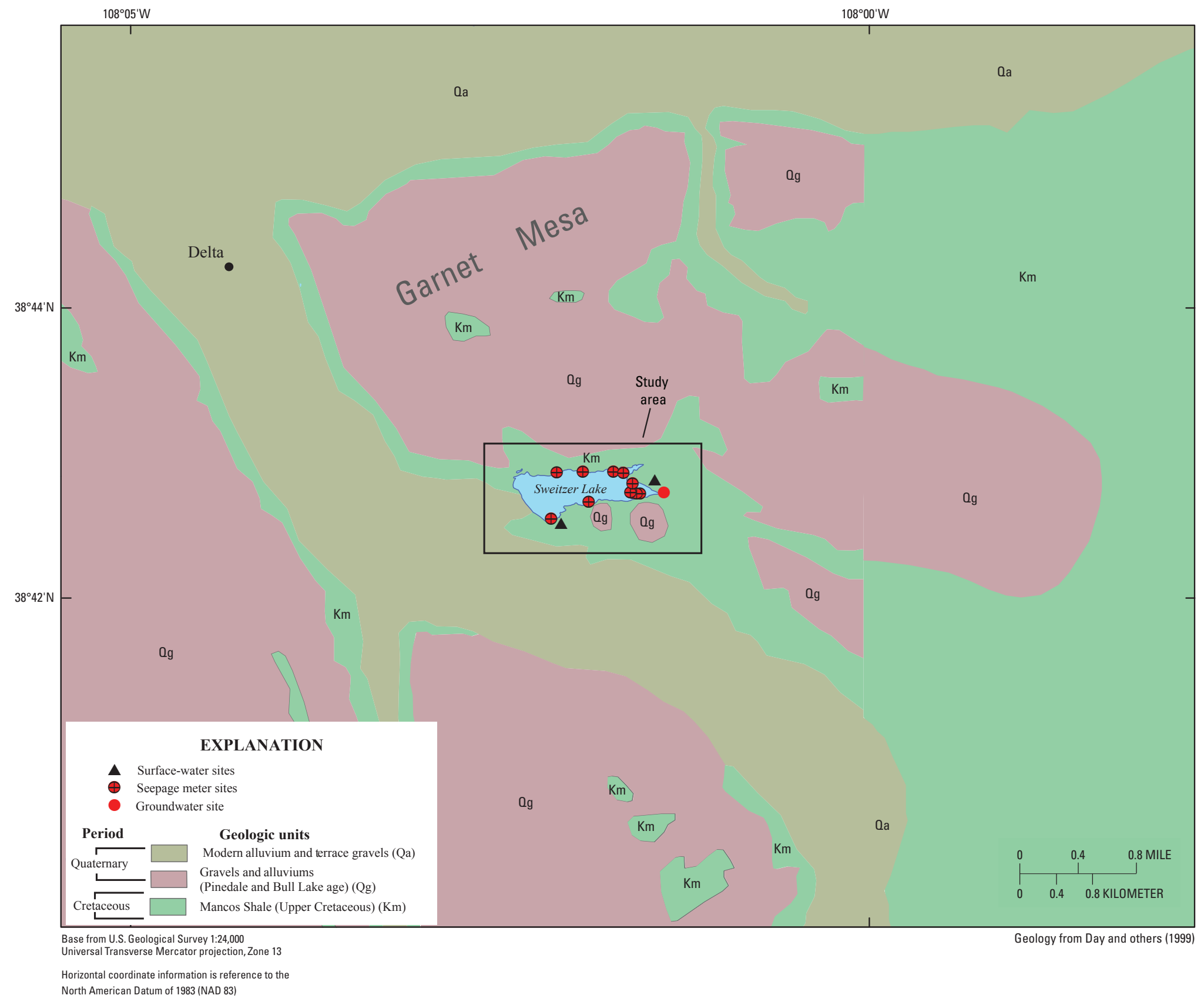

Figure 3. Selected geologic units outcropping adjacent to Sweitzer Lake, western Colorado. 


\section{Methods for Data Collection and Analysis of Selenium Loading}

Selenium loads to Sweitzer Lake can be estimated from the concentrations of selenium in and rates of flow of surface water and groundwater into the lake. Surface-water flow and groundwater flux into Sweitzer Lake were measured during October 2006 to October 2007. Groundwater flow into Sweitzer Lake was estimated for a range of hypothetical lake-bottom areas and the median of groundwater flux rates measured during the study. Concentrations of selenium were determined from surface-water and groundwater samples collected during October 2006 to October 2007. A multiple linear regression model was developed for estimating daily mean selenium concentration using the FORTRAN program LOAD ESTimator (LOADEST) (Runkel and others, 2004) for both surface-water sites. Load reductions were determined for surface water and groundwater that represent the amount of selenium load (pounds annually) that would need to be reduced in order to meet the chronic standard (85th percentile selenium concentration of $4.6 \mu \mathrm{g} / \mathrm{L}$ (micrograms per liter)). The 85 th percentile selenium concentration for surface-water sites is determined from predicted daily mean selenium concentration during the study period (October 2006 to October 2007). Selenium concentration data were too sparse to determine the 85th percentile selenium concentration for groundwater; therefore, all available selenium concentrations for groundwater were used to determine groundwater load reductions.

\section{Data Collection}

Surface-water and groundwater measurements and samples were collected from October 2006 to October 2007 to measure streamflow and groundwater flux, to determine selenium concentrations in inflow to Sweitzer Lake. These data were used to calculate selenium loads into Sweitzer Lake. Surface-water data were collected at Garnet Canal Diversion at Sweitzer Lake (site SW-1) and Diversion Drain at Sweitzer Lake (site SW-2) (fig. 1). Groundwater flux data were collected at 10 seepage-meter sites in the lake, and groundwaterquality samples were collected at a groundwater seep (seep-1) and from groundwater discharge into the Garnet Canal Diversion during January 2007 (at site SW-1). It is assumed that because the January 2007 sample collected near site SW-1 was collected during the nonirrigation season that the source of this water is groundwater.

\section{Streamflow and Continuous Water-Quality Data Collection}

From October 2006 to October 2007, continuous streamflow and water-quality data were collected at surface-water sites $\mathrm{SW}-1$ and $\mathrm{SW}-2$. Streamflow was determined from the continuous stage record and the stage-discharge rating table that was developed using periodic instantaneous streamflow and stage measurements. Instantaneous streamflow was measured using methods described by Rantz and others (1982). YSI water-quality sondes were installed at sites SW-1 and SW-2 to collect continuous specific conductance and temperature data using methods described in Wagner and others (2006).

\section{Groundwater Flux Data Collection}

Groundwater flow into the lake cannot be measured directly but is estimated based on point measurements of flux across the lake bottom. Thus, groundwater-flow estimates are less accurate than the measured surface-water flows. In order to estimate groundwater flow into Sweitzer Lake, it was necessary to measure the groundwater flux, or rate and direction of flow per unit area, at selected sites in Sweitzer Lake and to estimate the relative areas of lakebed with positive flux (subsurface inflow to the lake) and negative flux (subsurface outflow from the lake). This assessment provides an approximation of relative lakebed areas with positive or negative flux. A more detailed study would be needed to provide a more refined estimate of relative lakebed areas with positive and negative flux.

Ten seepage meters (Lee, 1977; Rosenberry and LaBaugh, 2008) were installed in Sweitzer Lake to quantify groundwater flux across the bottom of Sweitzer Lake. An increase in the volume of water in a seepage-meter collection bag indicates a positive groundwater flux (or inflow of groundwater), whereas a decrease in the volume of water in a seepage-meter collection bag indicates a negative groundwater flux (or outflow of groundwater). Seepage meters were constructed from the top half of a 55-gallon polyvinyl chloride barrel and were installed by embedding the open portion of each barrel approximately 2 feet into lake-bottom sediments at 10 locations adjacent to Garnet Canal and around wetland areas where seepage into the lake was probable (fig. 1). Most meters were placed at depths of 3 to 4 feet below the water surface with a maximum depth of less than 10 feet. Seepage rate (flux) was measured on four occasions during the study period, during the months of October 2006, twice during April 2007, and June 2007. There are many sources of error associated with data collected using a seepage meter. These can include incomplete seal between seepage-meter chamber and sediments, which can be due to an unstable cylinder; improper bag-attachment procedures, bag resistance, and moving water; leaks; measurement error; insufficient or excessive bag-attachment time; and accumulation of trapped gas (Rosenberry and LaBaugh, 2008). Other variables affecting groundwater flux include irrigation ditch operations, soil moisture conditions, and fluctuations in the water table near Sweitzer Lake. The average flux for each site was used to represent a positive or negative flux unless otherwise noted. The median of the absolute value of all seepage meter measurements was used when 
calculating selenium load estimates because it is an estimate of the groundwater flow velocity (both into or out of the lake).

\section{Water-Quality Data Collection}

Surface-water and groundwater-quality samples were collected during the study period to determine concentrations of selenium of contributing sources to Sweitzer Lake. Seven water-quality samples were collected at Garnet Canal Diversion (site SW-1), five were collected at Diversion Drain (site SW-2), and two at Groundwater Seep No.1 near Sweitzer Lake, Colo. (seep-1), during the study period (fig. 1). Seep-1 was a one-foot-deep hole that was dug on the eastern end of Sweitzer Lake in a marshy area in which groundwater was observed to be seeping to the surface. For the water-quality samples collected in October 2006 and April 2007, a hole was dug and left for several hours to provide the opportunity for groundwater to flow into the hole. After several hours, waterquality samples were collected from the hole. In addition to groundwater-seepage samples, a water-quality sample collected at Garnet Canal Diversion site ( $\mathrm{SW}-1$ ) during January 2007 was assumed to represent groundwater selenium concentrations as it could be assumed that the source of water during the nonirrigation season is groundwater seepage. Water-quality samples were collected and processed using standard protocols (U.S. Geological Survey, variously dated).

No water-quality samples were collected from Sweitzer Lake during the study period. The USGS and CDPHE collected some selenium concentration data in Sweitzer Lake previously. USGS data were retrieved from USGS National Water Information System (NWIS) (http://waterdata.usgs.gov/ nwis), and CDPHE data were retrieved from the U.S. Environmental Protection Agency's (USEPA) STOrage and RETrieval (STORET) database (http://www.epa.gov/storet). USGS collected 11 selenium concentration samples from three locations in Sweitzer Lake (near shore, midlake, and near the dam) from 1973 to 2000. Samples were collected at depths ranging from 1 foot to 25 feet at the three locations in the lake. Selenium concentrations for these samples ranged from 6 to $25 \mu \mathrm{g} / \mathrm{L}$, with a median selenium concentration of $14 \mu \mathrm{g} / \mathrm{L}$. CDPHE collected three selenium concentration samples in Sweitzer Lake at three locations (two locations near the dam and one midlake location) in August 2005. Selenium concentrations for these three samples ranged from 8.4 to $10 \mu \mathrm{g} / \mathrm{L}$.

Quality-assurance and quality-control (QA/QC) samples for this study included a field blank and a replicate. No selenium was detected in the field blank sample, and there was no variability of selenium concentration in the replicate sample. Field-blank results were used to determine that analytical results were not biased by contamination of the sample from the sampling equipment, equipment cleaning, and sample processing. Replicate samples were used to determine that variability in sample results was minimal. Water-quality samples were shipped to the USGS National Water Quality Laboratory for dissolved selenium analysis (Garbarino and others, 2006). Data are presented here (tables 1, 2, 3, and 4) and are available from NWIS through the Web at http://waterdata.usgs.gov/co/ nwis.

\section{Selenium Load Estimates and Load Reductions}

\section{Load Estimation for Surface Water Using Regression Analysis}

LOAD ESTimator (LOADEST), a Fortran program for estimating constituent loads in streams and rivers (Runkel and others, 2004), was used to estimate daily mean selenium concentration for both surface-water sites. LOADEST provides users the ability to develop a multiple-linear regression model for estimating constituent loads or concentrations over a user-specified time period. Load estimates were derived in three steps - model development, calibration of the developed model, and estimates of loads using the model. LOADEST provides 11 predefined regression models and also allows for modifying predefined models to create user-defined models. The user-defined model was created based on knowledge of irrigation practices in the study area and incorporating the

Table 1. Summary of regression model diagnostics for two surface-water sites that are sources of inflow to Sweitzer Lake, western Colorado, October 2006 to October 2007.

$\left[\mathrm{r}^{2}\right.$, the coefficient of determination; $\mathrm{p}$-value, value less than 0.05 is considered statistically significant; $\mu \mathrm{g} / \mathrm{L}$, micrograms per liter]

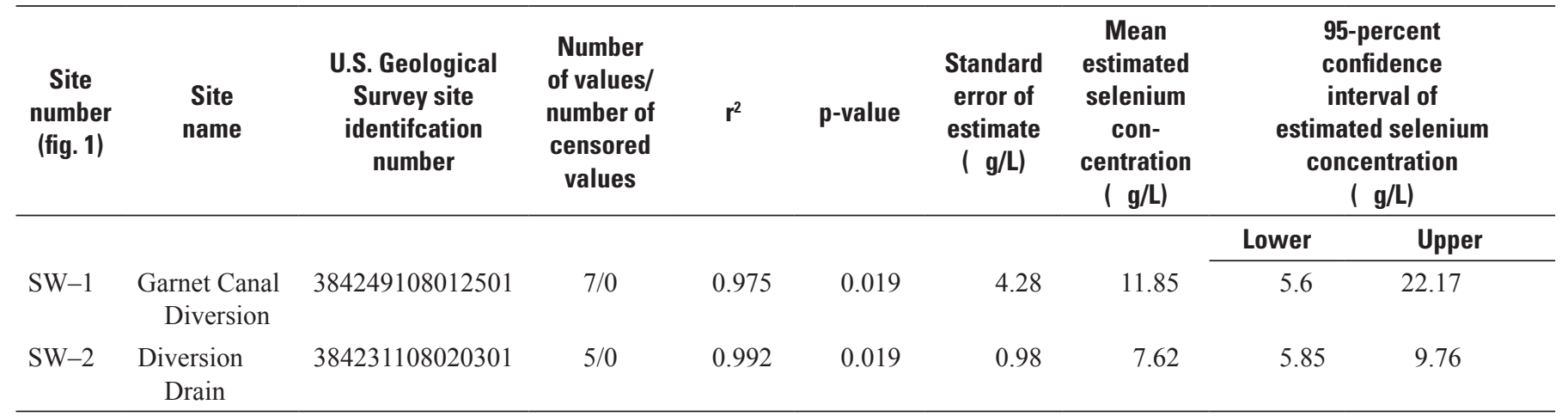


Table 2. Summary of groundwater flux data collected for each site indicating overall direction of groundwater flux at Sweitzer Lake, western Colorado, 0 ctober 2006 to October 2007.

[missing, seepage meter could not be located at time of sampling; Average flux, average of flux measurements at a site; Direction of flux, positive, overall flux at site was inflow to the lake; negative, overall flux at site was outflow from the lake; Median flux, median flux is the absolute value of all individual flux measurements (positive and negative) and is used for determining selenium loads in table 4]

\begin{tabular}{|c|c|c|c|c|c|c|c|c|c|c|c|}
\hline Date & $S M-1^{1}$ & SM-2 ${ }^{1}$ & SM-3' & SM-4' & SM-51 & $S M-6^{1}$ & $S M-7^{1}$ & SM-8' & SM-9' & \multicolumn{2}{|l|}{ SM-10 ${ }^{1}$} \\
\hline $10 / 06 / 2006$ & -0.00406 & -0.002501 & -0.00246 & -0.00174 & -0.00443 & 0.00459 & 0.00759 & -0.00346 & -0.0357 & \multicolumn{2}{|l|}{-0.0154} \\
\hline $04 / 14 / 2007$ & -0.00169 & 0.00199 & 0.00332 & -0.00272 & 0.00638 & -0.00227 & 0.00816 & -0.003295 & -0.0392 & \multicolumn{2}{|l|}{0.0173} \\
\hline $04 / 15 / 2007$ & -0.000882 & -0.000199 & 0.02012 & -0.00193 & 0.0105 & 0.00432 & 0.0276 & 0.00646 & -0.0335 & \multicolumn{2}{|l|}{0.0262} \\
\hline $06 / 13 / 2007$ & missing & missing & -0.00305 & -0.00201 & 0.00448 & 0.00683 & 0.0260 & -0.000323 & -0.0256 & \multicolumn{2}{|l|}{0.00153} \\
\hline Average flux & -0.00221 & -0.00024 & 0.00448 & -0.00210 & 0.00423 & 0.00337 & 0.01733 & -0.00015 & -0.03350 & 0.00741 & Median flux \\
\hline Direction of flux & negative & negative & positive & negative & positive & positive & positive & negative & negative & positive & 0.00438 \\
\hline
\end{tabular}

${ }^{1}$ Flux at each site, flux in feet per day.

Table 3. Estimated selenium concentration and loads in surface-water inflow to Sweitzer Lake, western Colorado, October 2006 to 0 ctober 2007.

$[\mu \mathrm{g} / \mathrm{L}$, micrograms per liter; 85 th percentile, 85 th percentile of modeled selenium concentration; daily mean load, pounds per day; annual load, pounds per year; annual load reduction, pounds per year of selenium load that needs to be reduced to bring contributing source into compliance with water-quality standards; Percent annual load reduction, percentage of total load that needs to be reduced per year to bring contributing source into compliance with water-quality standards]

\begin{tabular}{|c|c|c|c|c|c|c|c|c|c|}
\hline $\begin{array}{c}\text { Site } \\
\text { number } \\
\text { (fig. 1) }\end{array}$ & $\begin{array}{c}\text { Site } \\
\text { name }\end{array}$ & $\begin{array}{l}\text { Range of sele- } \\
\text { nium concen- } \\
\text { trations ( } \mu \mathrm{g} / \mathrm{L})\end{array}$ & $\begin{array}{l}\text { Median sele- } \\
\text { nium concentra- } \\
\text { tion }(\mu \mathrm{g} / \mathrm{L})\end{array}$ & $\begin{array}{c}\text { 85th } \\
\text { percentile } \\
(\mu \mathrm{g} / \mathrm{L})\end{array}$ & $\begin{array}{c}\text { Range of } \\
\text { daily mean } \\
\text { loads }\end{array}$ & $\begin{array}{c}\text { Average } \\
\text { daily mean } \\
\text { load }\end{array}$ & $\begin{array}{c}\text { Annual } \\
\text { load }\end{array}$ & $\begin{array}{l}\text { Annual } \\
\text { load } \\
\text { reduction }\end{array}$ & $\begin{array}{l}\text { Percent annual } \\
\text { load reduction }\end{array}$ \\
\hline SW-1 & Garnet Canal Diversion & $0-239$ & 11.8 & 17.2 & $0-1.67$ & 0.134 & 48.9 & 35.9 & 73 \\
\hline SW-2 & Diversion Drain & $0-356$ & 5.52 & 7.65 & $0-3.47$ & 0.0503 & 18.4 & 7.32 & 40 \\
\hline
\end{tabular}


Table 4. Summary of ground-water selenium concentration and load scenarios to Sweitzer Lake, western Colorado, October 2006 to 0 ctober 2007.

[selenium concentration, in micrograms per day; daily load, pounds per day; annual load, pounds per year; annual load reduction, pounds per year; USGS NWIS http://waterdata.usgs.gov/nwis]

\begin{tabular}{|c|c|c|c|c|c|c|c|c|c|c|c|c|c|c|c|c|}
\hline \multirow{2}{*}{$\begin{array}{l}\text { Percent- } \\
\text { age } \\
\text { of lake } \\
\text { bottom } \\
\text { with } \\
\text { positive } \\
\text { flux }\end{array}$} & \multirow{2}{*}{$\begin{array}{c}\text { Acres } \\
\text { of } \\
\text { lake } \\
\text { bottom } \\
\text { with } \\
\text { positive } \\
\text { flux }\end{array}$} & \multirow{2}{*}{$\begin{array}{c}\text { Square } \\
\text { feet } \\
\text { of lake } \\
\text { bottom } \\
\text { with } \\
\text { positive } \\
\text { flux }\end{array}$} & \multicolumn{2}{|c|}{ Inflow } & \multicolumn{3}{|c|}{$\begin{array}{l}\text { Selenium concentration } \\
\text { scenarios A-C }\end{array}$} & \multicolumn{3}{|c|}{$\begin{array}{l}\text { Daily selenium loads based on } \\
\text { selenium concentration } \\
\text { scenarios A-C }\end{array}$} & \multicolumn{3}{|c|}{$\begin{array}{l}\text { Annual selenium loads based on } \\
\text { selenium concentration } \\
\text { scenarios A-C }\end{array}$} & \multicolumn{3}{|c|}{$\begin{array}{l}\text { Annual selenium load } \\
\text { reductions based on selenium } \\
\text { concentration scenarios A-C } \\
\text { as 85th percentile selenium } \\
\text { concentrations }\end{array}$} \\
\hline & & & $\begin{array}{c}\text { cubic } \\
\text { feet/ } \\
\text { day } \\
1\end{array}$ & $\begin{array}{l}\text { cubic feet/ } \\
\text { second }\end{array}$ & $\begin{array}{c}\text { Sce- } \\
\text { nario } \\
\text { A } 2\end{array}$ & $\begin{array}{l}\text { Scenario } \\
\text { B } 3\end{array}$ & $\begin{array}{l}\text { Scenario } \\
\text { C } 4\end{array}$ & $\begin{array}{c}\text { Daily } \\
\text { load } \\
\text { scenario } \\
\text { A }\end{array}$ & $\begin{array}{l}\text { Daily } \\
\text { load } \\
\text { scenario } \\
\text { B }\end{array}$ & $\begin{array}{l}\text { Daily } \\
\text { load } \\
\text { scenario } \\
\text { C }\end{array}$ & $\begin{array}{c}\text { Annual } \\
\text { load } \\
\text { scenario } \\
\text { A }\end{array}$ & $\begin{array}{l}\text { Annual } \\
\text { load } \\
\text { scenario } \\
\text { B }\end{array}$ & $\begin{array}{l}\text { Annual } \\
\text { load } \\
\text { scenario } \\
\text { C }\end{array}$ & $\begin{array}{l}\text { Annual } \\
\text { load } \\
\text { reduction } \\
\text { scenario } \\
\text { A }\end{array}$ & $\begin{array}{l}\text { Annual } \\
\text { load } \\
\text { reduction } \\
\text { scenario } \\
\text { B }\end{array}$ & $\begin{array}{l}\text { Annual } \\
\text { load } \\
\text { reduction } \\
\text { scenario } \\
\text { C }\end{array}$ \\
\hline $75 \%$ & 102.75 & $4,475,790$ & 19,559 & 0.2264 & 198 & 36.7 & 19.7 & 0.242 & 0.0448 & 0.0241 & 88.3 & 16.3 & 8.8 & 86.3 & 14.3 & 6.8 \\
\hline $50 \%$ & 68.5 & $2,983,860$ & 13,039 & 0.1509 & 198 & 36.7 & 19.7 & 0.161 & 0.0298 & 0.0161 & 58.9 & 10.9 & 5.9 & 57.5 & 9.5 & 4.5 \\
\hline $40 \%$ & 54.8 & $2,387,088$ & 10,432 & 0.1207 & 198 & 36.7 & 19.7 & 0.129 & 0.0239 & 0.0129 & 47.1 & 8.7 & 4.7 & 46.0 & 7.6 & 3.6 \\
\hline $30 \%$ & 41.1 & $1,790,316$ & 7,824 & 0.0906 & 198 & 36.7 & 19.7 & 0.0967 & 0.0179 & 0.0096 & 35.3 & 6.54 & 3.52 & 34.5 & 5.72 & 2.70 \\
\hline $20 \%$ & 27.4 & $1,193,544$ & 5,216 & 0.0604 & 198 & 36.7 & 19.7 & 0.0645 & 0.0119 & 0.0064 & 23.6 & 4.36 & 2.35 & 23.0 & 3.81 & 1.80 \\
\hline $10 \%$ & 13.7 & 596,772 & 2,608 & 0.0302 & 198 & 36.7 & 19.7 & 0.0322 & 0.0060 & 0.0032 & 11.8 & 2.18 & 1.17 & 11.5 & 1.91 & 0.900 \\
\hline
\end{tabular}

${ }^{1}$ Using median ground-water flux $=0.00438$ feet per day estimated from seepage meters (see table 3).

${ }^{2}$ Selenium concentration collected at Garnet Canal Diversion SW-1 (U.S. Geological Survey site identifier 384249108012501), on 01/31/2007 (presumed to be dominantly ground water).

${ }^{3}$ Selenium concentration collected at Ground-water Seep No. 1 near Garnet Mesa Reservoir, Colo. (U.S. Geological Survey site identifier 384244108012101), on 04/10/2007.

${ }^{4}$ Selenium concentration collected at Ground-water Seep No. 1 near Garnet Mesa Reservoir, Colo. (U.S. Geological Survey site identifier 384244108012101), on 10/26/2006. 
continuous specific-conductance data that were collected as part of this study. Specific conductance is an indication of the amount of dissolved material (for example, selenium) that is in natural waters (Hem, 1985) and is expressed in this report as microsiemens per centimeter at 25 degrees Celsius $(\mu \mathrm{S} / \mathrm{cm}$ at $25^{\circ} \mathrm{C}$ ). Because specific conductance indicates the amount of dissolved material, it is a useful surrogate in detecting dissolved selenium. A plot of specific conductance in relation to selenium concentration data collected for this study at SW-1 and SW-2 reveals a positive linear relation between selenium concentration and specific conductance (fig. 4). From October 2006 to October 2007, daily mean selenium concentration, in micrograms per liter, was estimated at both surface-water sites using the following regression model:

$$
\text { Daily mean }[\mathrm{Se}]=\mathrm{a}_{0}+\mathrm{a}_{1} \text { per }+\mathrm{a}_{2} \operatorname{lnSC}+\mathrm{a}_{3} \operatorname{lnSCper} \text {, }
$$

where

$$
\begin{aligned}
& \text { [Se] is selenium concentration, in micrograms } \\
& \text { per liter; } \\
& \text { per is a dummy variable having a value of } 0 \text { or } 1 \text {; } \\
& \text { SC is daily mean specific conductance, in } \\
& \text { microsiemens per centimeter; and } \\
& \mathrm{a}_{\mathrm{n}} \text { are model coefficients where } \mathrm{n}=0,1,2, \ldots, \mathrm{n} \text {. }
\end{aligned}
$$

Explanatory variables used for this regression model include variables that describe selenium concentration dependence on specific conductance and using a dummy variable (per) to define irrigation water use. The dummy variable was assigned a value of either 1 or 0 to indicate the irrigation season. November through April is the nonirrigation season and per was assigned a value of 1 , whereas May through October is considered the irrigation season and per was assigned a value of 0 . During the nonirrigation season, because per is equal to 1 , the equation that defines selenium concentration looks like equation 1 and contains all four variables. The four-variable equation is needed during the nonirrigation season to account for the periods when no streamflow is occurring, which results in a dataset that contains many zero values for specific conductance. During the irrigation season, because per is equal to 0 , two of the variables in equation 1 drop out, leaving the equation with two variables for predicting selenium concentration. For both sites SW-1 and SW-2, more than 95 percent of the variability in the data was explained by the regression model; the regression models were significant at the 5-percent level $(\mathrm{p}<0.05)$ (table 1$)$ and in residual plots generally showed constant variance throughout the range of prediction.

Model coefficients were developed using ordinary least-squares (OLS) regression. OLS is a method for linear regression that estimates unknown quantities in a statistical model by minimizing the sum of the residuals squared, where residuals equal the difference between the predicted and observed values (Helsel and Hirsch, 1992). Evaluation of a model's significance included looking at the following diagnostics: the coefficient of determination $\left(r^{2}\right), p$-values, residual plots, and the standard error of estimate. Generally, a model exhibited poor correlation if the $\mathrm{r}^{2}$ value was less than 0.6 and the $\mathrm{p}$-value was greater than 0.05 . Residual plots were evaluated to confirm normality and constant variance throughout the range of prediction (homoscedasticity) (Helsel and Hirsch, 1992). Serial correlation also was evaluated by using residual plots (where a residual is an estimated value minus its corresponding observed value) related to loading concentration estimates and time. The presence of a serial correlation indicates that sampling bias or a trend may exist in the data set. All diagnostics were considered collectively to determine the most appropriate regression model (Helsel and Hirsch, 1992). Daily mean selenium concentrations were estimated using the calibrated regression equation and a time series of daily mean specific-conductance values.

The primary load estimation method used within LOADEST was Adjusted Maximum Likelihood Estimation (AMLE) (Runkel and others, 2004). Daily selenium load, in pounds per day, was calculated by multiplying the estimated daily mean selenium concentration, in micrograms per liter, by the daily mean streamflow, in cubic feet per second, by the unit conversion factor $(0.005395)$. The annual load was then determined as the sum of all the daily mean loads for the study period, October 2006 to October 2007.

\section{Load Estimation for Groundwater}

Groundwater flux was measured on four occasions during the study period by using the 10 seepage meters discussed in the data-collection section ("Groundwater Flux Data Collection") in Sweitzer Lake (table 2; fig. 5). Two of the seepage meters (SM-1 and 2) were damaged prior to the fourth measurement in June 2007 and could not be measured. Sites SM-1, SM-2, SM-4, SM-8, and SM-9 generally indicated negative flux in both the magnitude and direction of flux values, whereas SM-3, SM-5, SM-6, SM-7, and SM-10 indicated positive flux (table 2). The average flux for each site was used to represent the positive or negative flux unless otherwise noted (table 2).

Detailed assessment of groundwater flow and chemistry characteristics was beyond the scope of this study. Because few data were available to quantify groundwater flux to Sweitzer Lake and to determine groundwater selenium concentrations, the groundwater selenium loads and load reductions represent a plausible range of selenium load from groundwater to Sweitzer Lake. A more detailed groundwater assessment would be needed to refine estimates of groundwater selenium loads to Sweitzer Lake.

Results from groundwater flux measurements (table 2; fig. 5) provide a general understanding of the direction and rate of flow between Sweitzer Lake and the surrounding shallow groundwater system. The general direction of groundwater flow to the lake is from north to southwest, where groundwater is entering Sweitzer Lake on the north side of the lake and groundwater is flowing out on the southwest side of the lake, based primarily on the magnitude of seepage at 


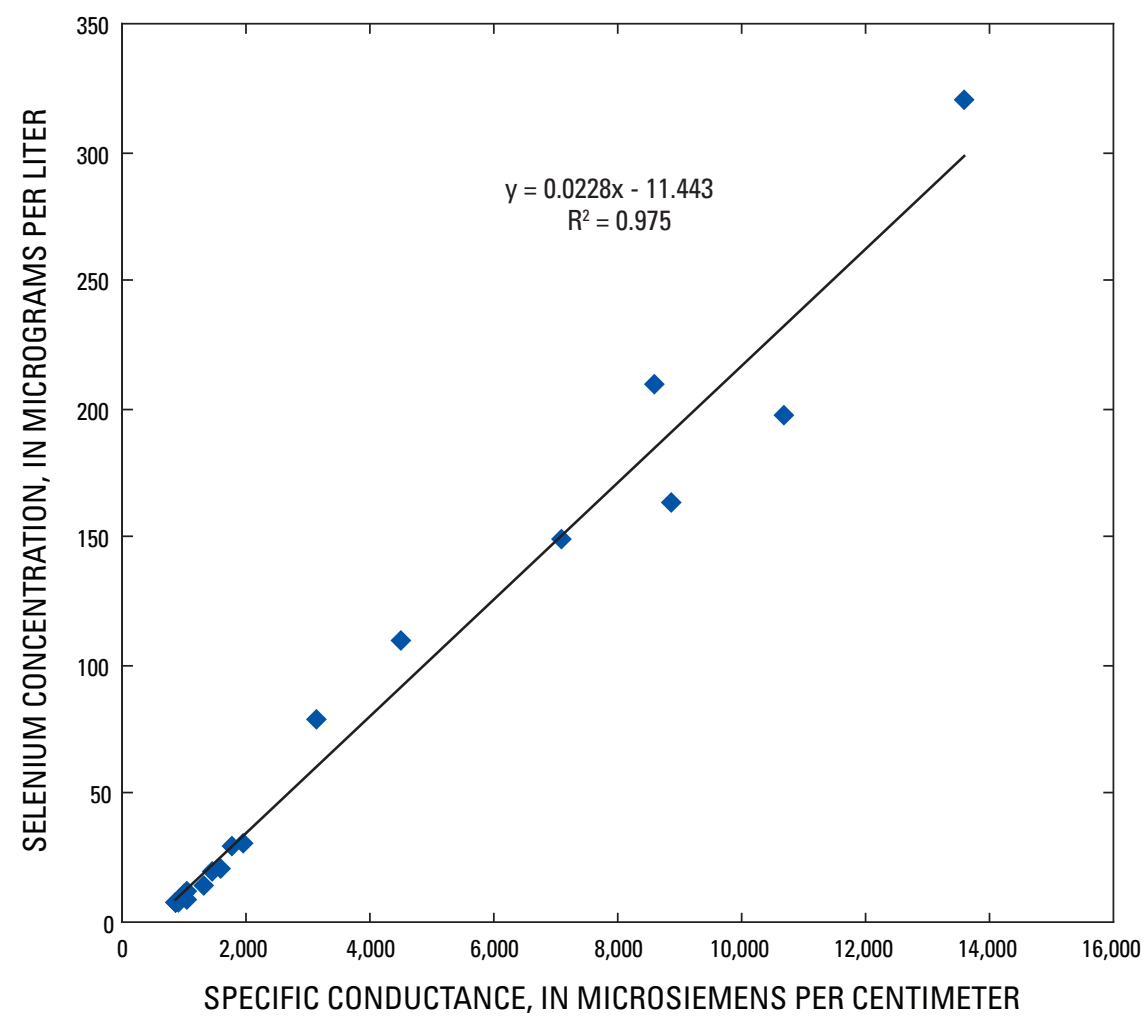

Figure 4. Scatter plot of instantaneous specific conductance in relation to selenium concentration data collected for this study at SW-1 and SW-2, October 2006 to October 2007.

SM-9. In order to determine the amount of selenium load to Sweitzer Lake from groundwater, the median of the absolute value of all individual seepage meter measurements was used as an estimate of the groundwater flux (0.00438) for Sweitzer Lake (table 2). The individual flux measurements indicate that positive and negative flux measurements were not appreciably different from one another; therefore, the median of the absolute value of seepage meter measurements was used because it is an estimate of the groundwater flow velocity (both into and out of the lake).

\section{Load Reductions}

Load reductions represent the amount of selenium load (pounds annually) that would need to be reduced for contributing source waters not to exceed the chronic standard (85th percentile selenium concentration of $4.6 \mu \mathrm{g} / \mathrm{L}$ (micrograms per liter)). All 85th percentile selenium concentrations were calculated in Microsoft Excel using the PERCENTILE function (Microsoft Corporation, 2003). Load reductions were calculated using a simple mass-balance approach. This approach assumed that the selenium load reduction would take place with no change in flow rates (streamflow or groundwater flow) and that only selenium would be removed from the contributing source water. On the basis of this assumption, a new selenium load was determined that equaled the load that would result if the 85th percentile selenium concentration were to equal the chronic standard of $4.6 \mu \mathrm{g} / \mathrm{L}$.

This method of estimating load reductions uses the ratio of the chronic standard to the 85th percentile selenium concentration for surface water or the single selenium concentration representing groundwater selenium concentration, which inherently preserves the distribution of the selenium concentrations through the year. The hypothetical load at compliance with the chronic standard was subtracted from the mean annual load, and the resulting value represents the amount of selenium load that would need to be reduced to bring the site into compliance with the chronic standard. Load reduction is defined by the following equation:

$$
\mathrm{L}_{\mathrm{R}}=\mathrm{L}_{\mathrm{A}}(1-\mathrm{STD}[\mathrm{Se}] / 85 \operatorname{th}[\mathrm{Se}]),
$$

where

$\mathrm{L}_{\mathrm{R}}$ is annual load reduction, in pounds, where annual refers to the study period from October 2006 to October 2007; 


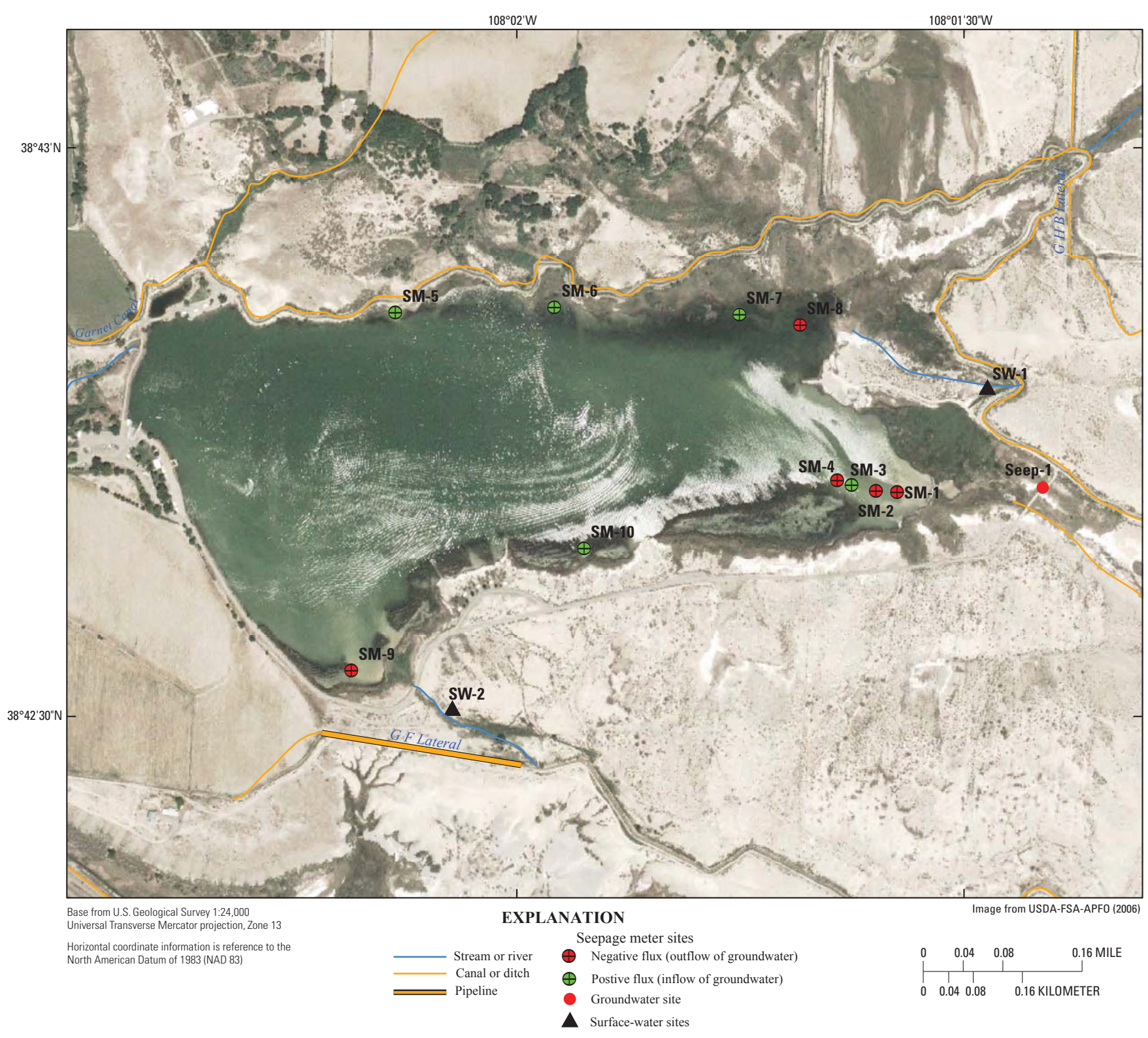

Figure 5. (on facing page) Results of groundwater flux analysis for Sweitzer Lake, western Colorado, October 2006 to October 2007. 
$\mathrm{L}_{\mathrm{A}}$ is annual load at the site, in pounds, where annual refers to the study period from October 2006 to October 2007;

STD [Se] is $4.6 \mu \mathrm{g} / \mathrm{L}$, the State chronic aquatic-life standard for dissolved selenium; and 85 th $[\mathrm{Se}]$ is the 85 th percentile selenium concentration for surface water or the single selenium concentration representing groundwater selenium concentration at a site, in micrograms per liter.

\section{Selenium Loading to Sweitzer Lake}

Loading analysis consisted of determining the 85th percentile selenium concentrations, daily mean and annual selenium loads, and annual load reductions. This section of the report contains a summary of surface-water and groundwater selenium loading to Sweitzer Lake. Streamflow and continuous water quality (specific conductance and water temperature) were monitored at two surface-water sites from October 2006 to October 2007. Daily mean specificconductance data were used in a regression model to estimate daily mean selenium concentrations, which were then applied with daily mean streamflow to the daily load equation (1) to determine the daily selenium load. Ten seepage meters were installed in Sweitzer Lake to quantify positive and negative flux to Sweitzer Lake. This information was used to estimate selenium load from groundwater inflow to Sweitzer Lake.

\section{Surface-Water Load}

From October 2006 to October 2007, selenium loads and load reductions were determined for two surface-water sites that discharge to Sweitzer Lake: Garnet Canal Diversion (site SW-1), and Diversion Drain (site SW-2). These two sites are located on canal spillways that flow into Sweitzer Lake.

Garnet Canal Diversion (site SW-1) is on the eastern end of Sweitzer Lake at the Garnet Canal spillway into Sweitzer Lake (fig. 1). The water source for Garnet Canal Diversion is a mixture of diversions from the Uncompahgre River, Loutzenhizer Arroyo, and an unnamed canal that flows into the Garnet Canal approximately 3,000 feet upstream from site SW-1 (Steve Fletcher, Olathe Delta Watermaster, Montrose, Colorado, oral commun., 2008). During the nonirrigation season, seep water was observed by USGS staff in both Loutzenhizer Arroyo and the unnamed canal. The source of this seep water is likely from the shallow groundwater system surrounding Sweitzer Lake. Daily mean selenium concentrations for site $\mathrm{SW}-1$ were estimated using LOADEST. Almost 98 percent of the variability $\left(r^{2}=0.975\right)$ in the data was explained, and the regression model was significant at the 5 percent level $(\mathrm{p}<0.02)$ (table 1$)$ and generally showed constant variance throughout the range of prediction in the residual plots. Daily mean selenium concentrations during the irrigation season were relatively constant and show little relation to fluctuations in daily mean streamflow (fig. $6 A$ ). Streamflow during the nonirrigation season was less than could be measured at the $\mathrm{SW}-1$ gage; however, water observed in the channel during the winter months was presumed to be groundwater. Modeled daily mean selenium concentrations for site $\mathrm{SW}-1$ ranged from 0 to $239 \mu \mathrm{g} / \mathrm{L}$, with a median of $11.8 \mu \mathrm{g} / \mathrm{L}$ and an 85 th percentile of $17.2 \mu \mathrm{g} / \mathrm{L}$ (table 3 ). All sampled selenium concentrations were greater than the chronic standard, and all modeled selenium concentrations were greater than the chronic standard during the irrigation season. Modeled selenium concentrations were generally equal to the acute standard during the irrigation season (fig. $6 A$ ). Daily mean selenium loads ranged from 0 to 1.67 pounds, with a mean daily selenium load of 0.134 pounds and a mean annual selenium load of 48.9 pounds. Seventy-three percent or 35.9 pounds of the annual selenium load would need to be reduced in order to meet the chronic standard.

Diversion Drain (site SW-2) is on the southwestern end of Sweitzer Lake at the G F Lateral spillway into Sweitzer Lake (fig. 1). The water source for Diversion Drain is the East Canal through the G F Lateral (a pipe conveys G F Lateral water across the Garnet Canal) (Steve Fletcher, oral commun., 2008). Daily mean selenium concentrations at site SW-2 were estimated using LOADEST. The regression model was significant at the 5-percent level $(\mathrm{p}<0.02)$ (table 1), and explained 99 percent of the variability in the data; model residuals generally showed constant variance throughout the range of prediction. Daily mean selenium concentrations during the irrigation season were relatively constant and show little correlation to fluctuations in daily mean streamflow (fig. 6B). There was no streamflow during the nonirrigation season, and the channel was observed to be dry. Daily mean selenium concentrations calculated at site SW-2 ranged from 0 to $356 \mu \mathrm{g} / \mathrm{L}$, with a median of $5.52 \mu \mathrm{g} / \mathrm{L}$ and an 85 th percentile of $7.65 \mu \mathrm{g} / \mathrm{L}$ (table 3). All sampled selenium concentrations were greater than the chronic standard but were less than the acute standard (fig. 6B). All modeled selenium concentrations during the irrigation season were greater than the chronic standard, and generally were less than the acute standard (fig. $6 B$ ). Daily mean selenium loads range from 0 to 3.47 pounds, with a mean daily selenium load of 0.0503 pounds and a mean annual selenium load of 18.4 pounds. Forty percent or 7.32 pounds of the mean annual selenium load would need to be reduced in order to meet the chronic standard.

Site SW-1 has greater selenium concentrations and loads than those at site SW-2, which can be attributed to the differences in source water for each of these sites. Site SW-1 receives approximately one-third of its streamflow from Loutzenhizer Arroyo (Steve Fletcher, oral commun., 2008). In a recent study of selenium concentrations and loads at Loutzenhizer Arroyo from 1991 to 2003, the average 85th percentile selenium concentration was $183 \mu \mathrm{g} / \mathrm{L}$ and the average of the mean annual selenium loads was 5,200 pounds (Thomas and others, 2008). 

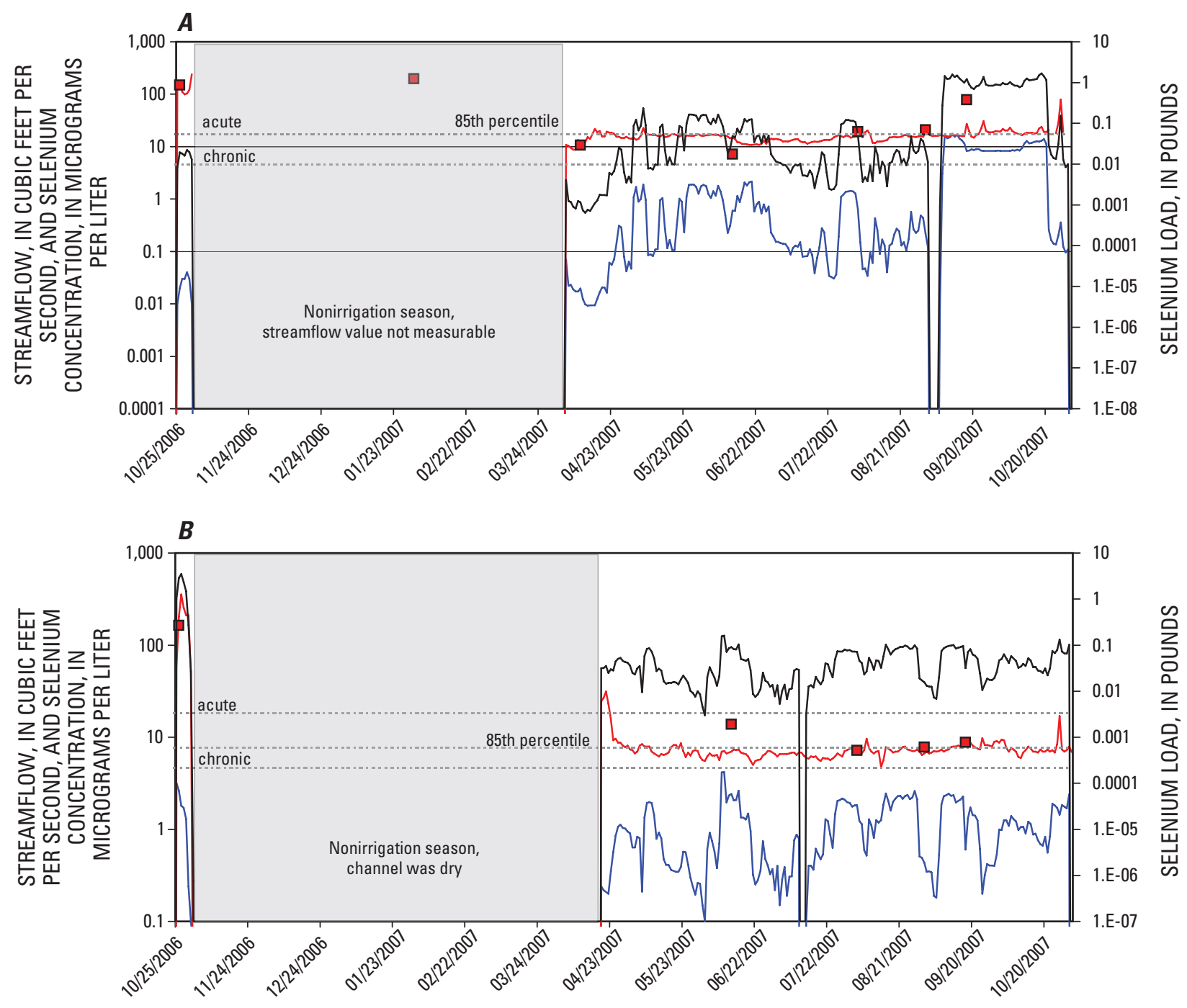

\section{EXPLANATION}

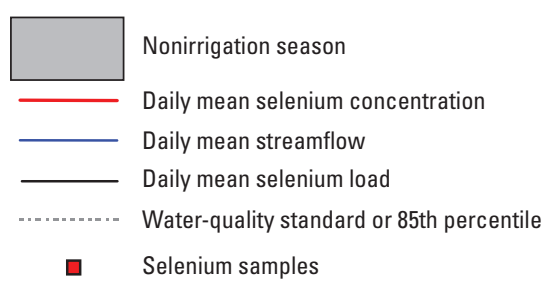

Figure 6. Time series plots of daily mean streamflow, selenium concentration, selenium load, and selenium samples for (A) Garnet Canal Diversion (site SW-1) and (B) Diversion Drain (site SW-2), near Sweitzer Lake, western Colorado. 


\section{Groundwater Load}

A range of areas with positive groundwater flux and a range of selenium concentrations in groundwater were used to provide a range of groundwater-selenium loads and load reductions for Sweitzer Lake (table 4). Relative proportions of lake bottom with positive or negative flux are not well quantified by this study; therefore, a range of 10 to 75 percent of the lake area was assumed to have positive flux and was used to provide a range of estimated selenium loads. Three groundwater selenium concentrations were used to provide a range of groundwater selenium loads to Sweitzer Lake (scenarios A through C, table 4; USGS NWIS http://waterdata.usgs. gov/nwis). Annual selenium loads ranged from 1.17 pounds to 88.3 pounds for the three scenarios over the range of lake areas (table 4). Selenium concentration data were too sparse to determine the 85th percentile selenium concentration; therefore, the available selenium concentrations were used to determine load reductions. Substituting the selenium concentrations from the three scenarios into the load-reduction equation (eq. 2) in place of the 85th percentile selenium concentration, annual load reductions ranged from 0.900 pound to 86.3 pounds over the range of lake areas (table 4). Groundwater selenium load and load reductions determined from this study identify the probable minimum and maximum values for these parameters. Further data collection and analysis could refine the range of groundwater selenium loads and load reductions.

\section{Summary}

Elevated selenium concentrations in streams are a water-quality concern in western Colorado. Sweitzer Lake was placed on the State 303(d) list as impaired with respect to dissolved selenium. In Colorado, the Water Quality Control Division (Division) of the Colorado Department of Public Health and Environment is required to develop total maximum daily loads of selenium for the 303(d) list segments. The U.S. Geological Survey, in cooperation with Colorado Department of Public Health and Environment, summarized selenium loading from surface water and groundwater to Sweitzer Lake to support the total maximum daily loads development process. This report provides a brief description of the study area, methods of data analysis, and results.

Results include the assessment of available selenium concentrations and loads, 85th percentiles of selenium concentration, and quantification of the amount of the selenium load (pounds annually) to Sweitzer Lake that would need to be reduced to bring the contributing sources (surface water and groundwater) into compliance with the State chronic aquatic-life standard for dissolved selenium, herein referred to as "a load reduction." From October 2006 to October 2007 , surface-water and groundwater data were collected to determine discharge and selenium concentration contribution to Sweitzer Lake. These data were used to determine the amount of the selenium load (pounds annually) that would need to be reduced to meet the State chronic aquatic-life standard of 4.6 micrograms per liter for dissolved selenium, herein referred to as "a load reduction." Selenium concentration data were also compared to the State acute aquatic-life standard of 18.4 micrograms per liter for dissolved selenium. Surface-water data were collected at Garnet Canal Diversion and Diversion Drain. Groundwater-flux data were collected at 10 seepage-meter sites in Sweitzer Lake, and groundwaterquality data were collected at a groundwater seep and from a sample collected at Garnet Canal Diversion during January 2007 when flow was presumed to be groundwater. A multiple linear regression model was selected for estimating daily mean selenium concentration using the Fortran program LOAD ESTimator (LOADEST) for both surface-water sites. Load reductions for surface water and groundwater used a simple mass-balance approach that assumed no change in streamflow or groundwater flow rates and that only selenium would be removed from the system. Load reductions represent the amount of selenium load (pounds annually) that would need to be reduced to meet the chronic standard (85th percentile selenium concentration of $4.6 \mu \mathrm{g} / \mathrm{L}$ ([micrograms per liter]).

Daily mean selenium concentrations at Garnet Canal Diversion during the irrigation season were relatively constant and show little relation to fluctuations in daily mean streamflow. Daily mean streamflow during the nonirrigation season was less than could be accurately measured; however, water was observed in the channel during the winter months and was presumed to be from the groundwater system. Daily mean selenium concentrations calculated at Garnet Canal Diversion (SW-2) ranged from 0 to $239 \mu \mathrm{g} / \mathrm{L}$, with a median of $11.8 \mu \mathrm{g} / \mathrm{L}$ and an 85 th percentile of $17.2 \mu \mathrm{g} / \mathrm{L}$. All sampled selenium concentrations were greater than the chronic standard, and all modeled selenium concentrations were greater than the chronic standard during the irrigation season. Modeled selenium concentrations were generally equal to the acute standard during the irrigation season. Daily mean selenium loads ranged from 0 to 1.67 pounds, with an average daily mean selenium load of 0.134 pound and an annual selenium load of 48.9 pounds. Seventy-three percent or 35.9 pounds of the annual selenium load would need to be reduced in order to meet the chronic standard. Daily mean selenium concentrations at Diversion Drain (SW-2) during the irrigation season were relatively constant and show little relation to fluctuations in daily mean streamflow. There was no streamflow during the nonirrigation season, and the channel was observed to be dry. Daily mean selenium concentrations calculated at Diversion Drain ranged from 0 to $356 \mu \mathrm{g} / \mathrm{L}$, with a median of $5.52 \mu \mathrm{g} / \mathrm{L}$ and an 85 th percentile of $7.65 \mu \mathrm{g} / \mathrm{L}$. All sampled selenium concentrations were greater than the chronic standard but were less than the acute standard. All modeled selenium concentrations during the irrigation season were greater than the chronic standard and generally were less than the acute standard. Daily mean selenium loads ranged from 0 to 3.47 pounds, with an average daily mean selenium load of 0.0503 pound and an annual selenium load of 18.4 pounds. Forty percent or 
7.32 pounds of the mean annual selenium load would need to be reduced in order to meet the chronic standard. Selenium concentrations and loads at Garnet Canal Diversion were higher than those at Diversion Drain, which can be attrib- $\square$ uted to the differences in source water for each of these sites. Garnet Canal Diversion receives approximately one-third of its streamflow from Loutzenhizer Arroyo. In a recent study of selenium concentrations and loads at Loutzenhizer Arroyo from 1991 to 2003, the average 85th percentile selenium con- $\square$ centration was $183 \mu \mathrm{g} / \mathrm{L}$ and the average of the mean annual selenium loads was 5,200 pounds.

A range of lake-bottom areas with positive groundwater flux and a range of selenium concentrations in groundwater were used to estimate ranges of groundwater-selenium loads and load reductions for Sweitzer Lake. Relative proportions of lake bottom with positive or negative flux were not well defined by this study, therefore, a range of 10 to 75 percent of the lake area was assumed to have positive flux and was used for estimating selenium loads. Three groundwater selenium concentrations were used to calculate three selenium concen- $\square$ tration scenarios to provide a range of groundwater selenium loads to Sweitzer Lake. Annual selenium loads ranged from 1.17 pounds to 88.3 pounds for the three scenarios over the range of lake areas, and annual load reductions ranged from 0.900 pound to 86.3 pounds over the range of lake areas. Groundwater selenium load and load reductions determined from this study identify the probable minimum and maximum values for these parameters. Further data collection and analy- $\square$ sis could refine the range of groundwater selenium loads and load reductions.

\section{Acknowledgments}

The author of this report thanks the following individuals involved in this study: Ken Leib (USGS) for providing his technical expertise regarding selenium issues in western Colorado; John Mayo (USGS) for his assistance in data analysis; Paul Diaz, Jr. (USGS) for data collection and working streamgage and water-quality monitoring records; Steve Fletcher (Olathe Delta Watermaster) for his assistance in understanding irrigation canals in the study area; and

Steve Gerner (USGS), Ken Watts (USGS), and Phil Hegeman (CDPHE) for providing technical reviews.

\section{References Cited}

Butler, D.L., Krueger, R.P., Osmundson, B.C., Thompson, A.L., and McCall, S.K., 1991, Reconnaissance investigation of water quality, bottom sediment, and biota associated with irrigation drainage in the Gunnison and Uncompahgre River Basins and at Sweitzer Lake, west-central Colorado, 198889: U.S. Geological Survey Water-Resources Investigations Report 91-4103, 99 p.
Butler, D.L., Wright, W.G., Stewart, K.C., Osmundson, B.C., Krueger, R.P., and Crabtree, D.W., 1996, Detailed study of selenium and other constituents in water, bottom sediment, soil, alfalfa, and biota associated with irrigation drainage in the Uncompahgre Project Area and in the Grand Valley, west-central Colorado 1991-93: U.S. Geological Survey Water-Resources Investigations Report 96-4138, 136 p. .

Colorado Department of Public Health and Environment, 2007a, Colorado 303(d) lists: Information available on the Web, accessed August 29, 2007, at http://www.cdphe.state. co.us/wq/Assessment/TMDL/303dists.html

Colorado Department of Public Health and Environment, 2007b, Colorado's 1998 303(d) List and Related Water Quality Management Lists Text: Information available on the Web, accessed May 29, 2007, at http://www.cdphe.state. co.us/op/wqcc/SpecialTopics/303(d)/303dtext.pdf $\square$

Colorado Department of Public Health and Environment, 2007c, Water quality control commission regulations: Information available on the Web, accessed May 29, 2007, at http://www.cdphe.State.co.us/regulations/wqccregs/index. . html

Colorado State Parks, 2008, Sweitzer Lake State Park Publi- $\square$ cations, Sweitzer Lake State Park Fact Sheet: Information available on the Web, accessed April 11, 2008, at http:// parks.state.co.us/Parks/SweitzerLake/Publications/.

Day, W.C., Green, G.N., Knepper, D. H., Jr., Phillips, R.C., 1999, Spatial geologic data model for the Gunnison, Grand Mesa, Uncompahgre National Forests mineral assessment area, southwestern Colorado and digital data for the Lead- $\square$ ville, Montrose, Durango, and Colorado parts of the Grand Junction, Moab, and Cortez 1 degree $\mathrm{x} 2$ degrees geologic maps: U.S. Geological Survey Open-File Report 99-427, 1 computer optical disk. $\square$

Frankenberger, W.T., Jr., and Engberg, R.A., 1998, Environ-[ mental chemistry of selenium: New York, Marcel Dekker, Inc., $736 \mathrm{p} . \square$

Garbarino, J.R., Kanagy, L.K., and Cree, M.E., 2006, Determi-口 nation of elements in natural-water, biota, sediment, and soil samples using collision/reaction cell inductively coupled plasma-mass spectrometry: U.S. Geological Survey Tech- $\square$ niques and Methods, book 5, sec. B, chap. 1, 88 p. $\square$

Gunnison Basin Selenium Task Force, 2007, Current projects-Effects of changes in land use on selenium loading in the Whitewater, $\mathrm{CO}$, area: Information available on the Web, accessed February 14, 2007, at http://www. seleniumtaskforce.org/projects1.html

Helsel, D.R., and Hirsch, R.M., 1992, Statistical methods in water resources: New York, Elsevier, 522 p. 
Hem, J.D., 1985, Study and interpretation of the chemical characteristics of natural water: U.S. Geological Survey Water Supply Paper 2254, 264 p.

Lakin, H.W., and Byers, H.G., 1941, Selenium occurrence in certain soils in the United States, with a discussion of related topics-Sixth report: U.S. Department of Agriculture Technical Bulletin 783, 27 p.

Lee, D.R., 1977, A device for measuring seepage flux in lakes and estuaries: Limnology and Oceanography, v. 22, no. 1, p. $140-147$.

Lemly, A.D., 2002, Selenium assessment in aquatic ecosystems - a guide for hazard evaluation and water quality criteria: New York, Springer-Verlag, 3 p.

Microsoft Corporation, 2003, Microsoft Excel: Redmond, Wash., copyright (C) Microsoft Corporation 1985-2003.

Rantz, S.E., and others, 1982, Measurement and computation of streamflow: U.S. Geological Survey Water-Supply Paper $2175,631 \mathrm{p}$.

Rosenberry, D.O., and LaBaugh, J.W., 2008, Field techniques for estimating water fluxes between surface water and ground water: U.S. Geological Survey Techniques and Methods 4-D2, 128 p. [Available at http://pubs.er.usgs.gov/] usgspubs/tm/tm4D2]. [

Runkel, R.L., Crawford, C.G., and Cohn, T.A., 2004, Load estimator (LOADEST) - a FORTRAN program for estimat- $\square$ ing constituent loads in streams and rivers: U.S. Geological Survey Techniques and Methods, book 4, chap. A5, 69 p. $\square$

Seiler, R.L., 1997, Methods to identify areas susceptible to irrigation-induced selenium contamination in the western United States: U.S. Geological Survey Fact Sheet 038-97, 4 p. [Available at http://pubs.er.usgs.gov/usgspubs/fs/] fs03897]. [

Thomas, J.C., Leib, K.J., Mayo, J.W., 2008, Analysis of dissolved selenium loading for selected sites in the Lower Gunnison River Basin, Colorado, 1978-2005: U.S. Geological Survey Scientific Investigations Report 2007-5287, $25 \mathrm{p}$.

U.S. Census Bureau, 2008, Population finder: Information available on the Web, accessed March 20, 2008, at http:// www.census.gov/.
USDA-FSA-APFO, 2006, USDA-FSA-APFO Digital Ortho Mosaic: Information available on the Web, accessed May 12, 2008, http://gdw.apfo.usda.gov/naip/viewer/viewer.htm.

U.S. Geological Survey, variously dated, National field manual for the collection of water-quality data: U.S. Geological Survey Techniques of Water-Resources Investigations, book 9, chaps. A1-A9; Available online at http://pubs.water.usgs. gov/twri9A.

Vogelmann, J.E., S.M. Howard, L. Yang, C.R. Larson, B.K. Wylie, and J.N. Van Driel, 2001, Completion of the 1990's National Land Cover Data Set for the conterminous United States: Photogrammetric Engineering and Remote Sensing v. 67 , p. $650-662$.

Wagner, R.J., Boulger, R.W., Jr., Oblinger, C.J., and Smith, B.A., 2006, Guidelines and standard procedures for continuous water-quality monitors - Station operation, record computation, and data reporting: U.S. Geological Survey Techniques and Methods 1-D3, 51 p. +8 attachments; accessed April 10, 2006, at http://pubs.water.usgs.gov/tmld3

Western Regional Climate Center, 2008, Colorado climate summaries: Information available on the Web, accessed May 9, 2008, at http://www.wrcc.dri.edu/summary/ climsmco.html

Wright, W.G., and Butler, D.L., 1993, Distribution and mobilization of dissolved selenium in ground water of the irrigated Grand and Uncompahgre Valleys, western Colo- $\square$ rado, in Allen, R.G., and Neale, C.M.U., eds., Management of irrigation and drainage systems - Integrated perspectives: American Society of Civil Engineers, Proceedings of the 1993 National Conference on Irrigation and Drainage Engi- $\square$ neering: Park City, Utah, July 21-23, 1993, p. 770-777.ם 
Publishing support provided by:

Denver Publishing Service Center

For more information concerning this publication, contact:

Director, USGS Colorado Water Science Center

Box 25046, Mail Stop 415

Denver, CO 80225

(303) 236-4882

Or visit the Colorado Water Science Center Web site at: http://co.water.usgs.gov/ 
